\title{
МОНГОЛ УЛС, БНСУ-ЫН ХУДАЛДААНЫ ХАРИЛЦАА
}

\section{И.Энхболд}

Монгол Улс, БНСУ-ьын худалдааны харилцааг судлахдаа юуны өмнө манай улсын худалдааны бодлого, хоёр улсын хоорондын худалдааны талаарх судлагдсан байдал, Монгол Улс, БНСУ-ылн худалдаань өнөөгийн байдал болон хоёр улсын худалдааны харилцааны талаар бага зэрэг үнэлэлт дүгнэлт өгөхийг хичээлээ. Өнгөрсөн жилүүдэд Хоёр улсын харилиаа улс төрийн хүрээнд өргөжсин тэлсэн боловч эдийн засгийн хүрээнд хангалттай түвшинд хүрсэнгүй. Энэ байдлыг сайжруулах хэд хэдэн аргын нэг нь Эдийн засгийн түншлэлийн хэлэлиээр байх болов уу гэсэн таамаглал гаргаж болох юм. Мөн 27 жилийн турш дурдагдаж буй том хэмжээний хөрөнгө оруулалтыг БНСУ-аас maтах нь хоёр улсын эдийн засгийн харилцаанд иинэ алхам болно гэдэгт итгэж байна.

Түлхүур үгс: Монгол Улс, БНСУ, гадаад худалдаа, хоёр улсын харилцаа

\section{1. Судлагдсан байдал}

Монгол Улс, БНСУ-ын худалдааны талаар судалсан бүтээл одоогоор маш хомс байгаа бөгөөд МУИС, Олон улсын харилцааны хүрээлэн, Чингис хаан дээд сургууль, БНСУ-ын KIEP, KOTRA, KITA, Дангүгийн Их Сургууль зэрэг тоотой хэдэн байгууллага, зарим хувь 
судлаачдын бүтээл, төслүүд байдаг. Тухайлбал:

2006 онд Монголын үйлдвэр худалдааны яам, Санта Кларагийн Их Сургуулийн багш Христиан Хелмерстэй хамтарсан судалгааны тайлан байдаг. Энэ судалгаанд БНХАУ, ОХУ, АНУ, Япон, БНСУ-тай Чөлөөт худалдааны хэлэлцээр хийх боломжийн талаар судалж Япон, БНСУ-тай Чөлөөт худалдааны хэлэлцээр байгуулсан тохиолдолд ашигтай байх магадлалтай гэсэн тооцоо хийжээ.

2006 онд Монгол банкны судалгааны хэлтсийн эдийн засагч Л.Даваажаргал нь Гравити загвар болон Итали, Их Британи, ОХУ, Хятад, Өмнөд Солонгос, АНУ, Канад гэсэн экспортын түнш 7 орон, Монголын 2000-2005 оны улирлын панел өгөгдлийг ашиглаж Монгол Улсын гадаад худалдаанд ханшийн хэлбэлзлийн үзүүлэх нөлөөг тооцсон байна. Эмпирик судалгааны үр дүнд ханшийн тодорхойгүй байдал болон гадаад худалдааны хооронд статистикийн хувьд ач холбогдолгүй эерэг хамаарал байгааг тогтоожээ. ${ }^{1}$

2006 онд БНСУ-ын эрдэмтэн Шим И Собын Монгол Улс, БНСУын ЧХХ хийх боломжийн талаарх судалгаанд эдийн засгийн хүчин чадлын ялгаа гол биш бөгөөд Монгол Улс нь зах зээлийн эдийн засгийн бүтцийг хэр зэрэг агуулж байна вэ гэдэг нь чухал хэмээгээд вертикал хэлбэрийн ЧХХ байгуулах боломжтой хэмээжээ.

2006 онд БНСУ-ын эрдэмтэн Ким Хун Жиний Монгол Улс, БНСУ-ын ЧХХ хийх боломжийн талаарх судалгаанд Ерөнхий тэнцвэрийн арга ба Гравитийн аргыг ашиглан шинжилгээ хийж хоёр улсын хооронд ЧХХ байгуулах нь эерэг үр дүнтэй гэсэн байна. Мөн эдийн засгийн шинжилгээний аргад тулгуурлахаас илүү бодит байдлыг дүгнэн үзэх шаардлагатай гэжээ. ${ }^{2}$

2007 онд судлаач Р.Амаржаргал Гравити загвар ашиглан газар зүйн хүчин зүйлсийг анхааралдаа авч болох гипотез маягийн ЧХГ-нд нэгдсэн нөхцөлд Монголын гадаад худалдаa хэрхэн өрнөж болохыг харуулсан юм. Судалгаанаас үзэхэд гадаад худалдааны нээлттэй бодлого явуулах, аль болохоор бүс нутгийн интеграцид нэгдэх, хоёр талын худалдааны гэрээ байгуулах замаар алслагдсан байдал, түүнээс

https:/www.mongolbank.mn/documents/tovhimol/group4/10.pdf.

2 Шим И Соб, Г.Мөнхнасан, ЗүҮн Хойд Азийн эрин үе ба Монгольн эдийн засаг, Сөүл, 2015, 152 дугаар тал. 
ҮҮдэж буй сөрөг үр дагаврыг Монгол давж чадна хэмээжээ. ${ }^{3}$

2008 онд МУИС-ийн багш Н.Батнасан БНХАУ, ОХУ-тай ЧХХ байгуулах нь эрсдэлтэй гэсэн дүгнэлтийг Ерөнхий тэнцвэрийн загвар (general equilibirium model) ашиглан гаргажээ.

2012 онд Н.Батнасан, Н.Отгонсайхан, Д.Нарандалай, Ц.Оюунбилэг нэр ОХУ, БНХАУ, Япон, БНСУ, АНУ, Канадтай Чөлөөт худалдааны хэлэлцээр байгуулах боломжийг Ерөнхий тэнцвэрийн загвар (general equilibirium) болон Гравити загвар(Gravity model) ашиглан судалсан. Үр дүнд нь Япон, БНСУ-тай ЧХХ хийх нь ашигтай бөгөөд 2020 он гэхэд 0.4-2.0 хувиар өсөх боломжтой хэмээн дүгнэжээ. ${ }^{4}$

2015 онд судлаач Шим И Соб болон Г.Мөнхнасан нарын “Монгол Улсын ЧХХ-ийн явц буюу БНСУ-тай ЧХХ байгуулах боломж” хэмээх өгүүлэлд Гравитийн загвараар панел өгөгдлийг ашиглан судалгаа хийсэн бөгөөд үр дүнд нь Монгол Улс, БНСУ-ын хооронд ЧХХ байгуулбал хоёр улсын худалдаа 6.1 дахин өснө гэсэн таамаглал дэвшүүлсэн байна. Мөн хоёр улсын ДНБ 1\% өсөхөд худалдаa $22.1 \%$ өсч, нэг хүнд ноогдох ДНБ $1 \%$ өсөхөд худалдаа $64.1 \%$ өсөх магадлалтай. Хоёр улсын хоорондох зай нь худалдааг $43 \%$ бууруулж, БНСУ-ын импортын татвар нь худалдааг 82.7 хувь багасгана гэсэн таамаглал дэвшүүлсэн байна. ${ }^{5}$

2015 онд судлаач Н.Отгонсайхан, М.Должин, Шим И Соб нарын "БНСУ ба Монгол Улсын хооронд Чөлөөт худалдааны хэлэлцээр байгуулах боломжийн тухай шинжилгээ” хэмээх өгүүлэлд Харьцангуй давуу тал (Revealed Comparative Advantage)ыг тодорхойлох индексийг ашиглан ямар бараа бүтээгдхүүнийг харилцан худалдаалах талаар дүн шинжилгээ хийжээ. Үүнд: МАА-н бүтээгдэхүүн, Уул уурхайн бүтээгдэхүүнүүд давуу талтай болохыг баталсан байна. БНСУ-д эдгээр бараа борлогдож чадах эсэхийг Импортын харьцангуй давуу талыг тодорхойлох индексээр тооцно гээд мөн дээрх 2 салбарын бүтээгдэхүүнийг экспортлох боломж өндөр болохыг нотолжээ. ${ }^{6}$

3 http://www.forum.mn/res_mat/tsuvral_amarjargal.pdf.

4 Н.Батнасан, Н.Отгонсайхан, Д.Нарандалай, Ц.Оюунбилэг, Худалдааньь гол түнш орнуудтай Чөлөөт худалдааны хэлэлцээр байгуулах боломж болон эрсдэл, Бодлогын судалгааны товч танилцуулга, Улаанбаатар, 2012.

5 Шим И Соб, Г.Мөнхнасан, ЗҮҮн Хойд Азийн эрин үе ба Монгольн эдийн засаг, Сөүл, 2015, 159 дүгээр тал.

6 Шим И Соб, Г.Мөнхнасан, ЗУҮн Хойд Азийн эрин уе ба Монголын эдийн засаг, 


\section{2. Монгол Улсын гадаад худалдааны өнөөгийн байдал}

Монгол Улсын гадаад худалдааны талаарх тоо баримт, судалгааны өгүүлэл, төслийн тайлангуудыг судлаад үзэхэд Хөдөө аж ахуйн салбарын бүтээгдэхүүнүүд, тэр дундаа малын гаралтай түүхий эд, зарим цөөн төрлийн ноос, ноолууран бүтээгдэхүүнүүд, Уул уурхайн салбараас гарч буй боловсруулаагүй түүхий эд, хүдрийн баяжмал зэрэг нь экспортын дийлэнх хэсгийг эзлэж, импортын хувьд өргөн хэрэглээний бараа, нефтийн бүтээгдэхүүн, машин, төнөг төхөөрөмж зэрэг нь ихэнх хувийг эзлэж байна. Нэмүү өртөг шингэсэн импортыг орлох, экспортыг дэмжих бүтээгдэхүүн үйлдвэрлэлийн талаар маш их дүгнэлт, санал гарсан байна. Монгол Улсын гадаад худалдааны хэмжээг графикаар харвал:

Экспорт Импорт /Мянган ам.доллар/

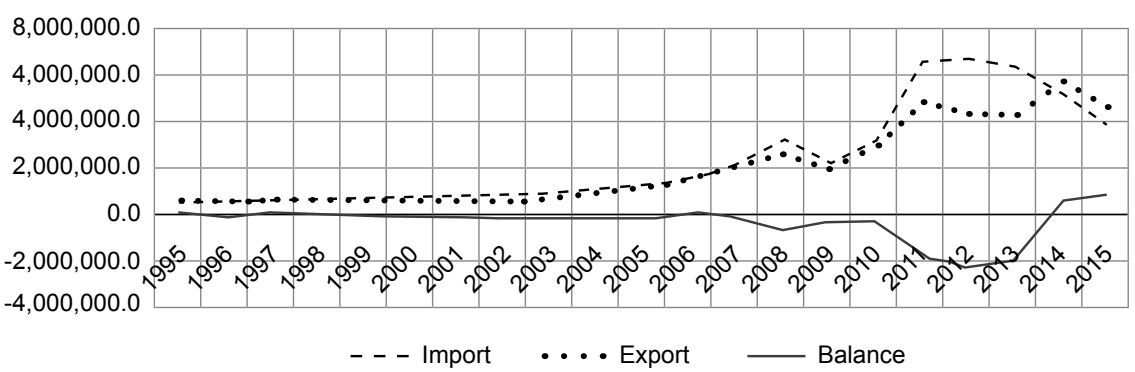

Source: http://customs.gov.mn/

Дээрх графикаас харахад Монгол Улсын гадаад худалдаа 2000 онд 2.3 тэрбум ам.долларын алдагдалтай явагдаж байсан бол 2015 онд 0.8 тэрбум ам.долларын ашигтай явагдсан байна. Энэ нь ихэвчлэн түүхий эдийн үнийн өсөлт, олон улс дахь түүхий эдийн эрэлттэй холбоотойгоор зарим жилд алдагдалтай, зарим жилд ашигтай явагддаг. Дотоод бодлогын хүчин зүйлээс бус гадаад зах зээлээс ихээхэн хамааралтай байдаг.

Монгол Улсын хувьд ямар хөрс суурин дээр гадаад худалдаа хийгдэж байгааг, ялангуяа БНСУ-тай хийх худалдааны үндсийг ойлгох нь чухал ач холбогдолтой. Энэ ойлголтыг илүү дөхөм болгохын тулд SWOT шинжилгээ хийх гэж оролдсон юм. Үүнд: Давуу тал:

Сөүл, 2015, 170 дугаар тал. 
1. Гадаад харилцааны хувьд чөлөөтэй, олон улстай найрсаг хамтын ажиллагаатай. Өнөөгийн байдлаар дэлхийн 186 оронтой албан ёсны дипломат харилцаа тогтоогоод байна. ${ }^{7}$ 1961 онд НҮБ-д элссэн бөгөөд өнөөдрийг хүртэл тогтвортой найдвартай байдлаа хадгалсаар ирсэн түүхтэй

2. Гадаад улсуудын аюул занал байхгүй харьцангуй тайван улсуудын тоонд зүй ёсоор багтдаг. Өөрөөр хэлбэл терроризмийн асуудал, дүрвэгсэдийн асуудал, хүний наймаа, хар тамхи, үндэстэн дамнасан мөнгө угаалт зэрэг уламжлалт бус аюул заналаас нэлээд сэргийлж чадсан. Түүнчлэн иргэний дайн, шашин хоорондын мөргөлдөөн, салан тусгаарлалт, улс төрийн олон төрлийн бослого зэрэг нь Монгол Улсад байхгүй гэж хэлж болох юм.

3. Өмнөд болон Хойд Солонгостой адил тэгш найрсаг харилцаатай. 1948 оны 10 дугаар сарын 15-ний өдөр БНАСАУ-тай, 1990 оны 3 дугаар сарын 26-ны өдөр БНСУтай албан ёсны дипломат харилцаа тогтоосон нь аль аль улсынх нь эрх ашиг, тусгаар тогтнол, бүрэн бүтэн байдлыг нь хүндэтгэн үзэж ирсэнийг илтгэн харуулна. Мөн “Улаанбаатарын яриа хэлэлцээ”, “Солонгосын нэгдлийн форум” зэрэг олон арга хэмжээг зохион байгуулж Солонгос үндэстний нэгдэлд өөрийн улсын хувь нэмрийг оруулахаар бүх талаар хичээж ажиллаж байна. Судлаач хүний нүдээр харвал БНСУ-ын Европ руу хандах эдийн засгийн бодлого нь ОХУ, БНХАУ гэхээсээ илүҮ Монгол Улс руу хандвал аль аль улсынх нь эрх ашигт нийцсэн хөгжлийн замыг сонгох боломж өндөр байх боломжтой харагддаг.

4. 1 сая 566 мянган км² газар нутагтай бөгөөд одоо нэг хүнд ноогдох газар нутгийн хэмжээгээр дэлхийд эхний байранд эрэмбэлэгдэж байна. Дэлхийд газар нутгийн хэмжээгээр 18 дугаарт ордог тул газар тариалан болон малын бэлчээрийн асар их нөөц байгааг дурдах нь зүйтэй.

5. Монгол Улсын нутаг дэвсгэрийн газрын доорх баялаг ихтэй. Коксжих нүүрс, зэс, алт, шатдаг занар, цайр, төмөр зэрэг ашигт малтмалууд арвин байх ба байгалийн баялаг ихтэй

7 http://www.mfa.gov.mn/?page_id=16448 
дэлхийн 10-н улсын тоонд бичигддэг.

6. Монгол Улс 2016 онд 61 сая гаруй мал тоолуулсан. Мал болон малын гаралтай түүхий эдийг боловсруулан экспортонд гаргах асар их боломж байгааг бид эндээс харж болох юм.

7. Хүн ам цөөн тул эдийн засгийн реформ хийх, хөрвөх чадвар өндөртэй. Монгол Улсын хүн ам 2016 оны 12 дугаар сарын 13-ны өдрийн байдлаар 3 сая 119 мянга 900 байна.

Сул тал:

1. Хүн ам цөөн тул худалдан авах зах зээл одоохондоо бага гэж ойлгож болно. Гэвч Сингапур, Израил зэрэг улсууд нь хүн ам бага ч гэсэн зах зээлийн хэмжээ том байдаг. Зөв шийдлээр хамтарч ажиллах чадвал энэ асуудлыг даван туулах боломжтой.

2. ОХУ, БНХАУ-ын хамаарал ихтэй. Гэвч Украин улсын хямралын дараа ОХУ-ын бодлого өөрчлөгдөж ЗХА руу чиглэх болсон. БНХАУ-ын өсөн нэмэгдэж буй зах зээлийн эрэлт хэрэгцээг хангах газар зүйн хувьд хамгийн ойр, байгалийн баялаг ихтэй улс нь Монгол Улс байдаг. Монгол Улсын байгалийн баялаг, БНСУ-ын менежмент, технологи, хөрөнгө оруулалт зэргийг нэгтгэн хамтран ажиллаж чадвал бидэнд боломж байна.

3. Далайд гарцгүй. Дэлхийн худалдааны байгууллагад элссэн давуу талаа ашиглан далайд гарцгүй орнуудын олон хөнгөлөлтийг хамтран эзэмших эрх бидэнд бий. 2015 оны байдлаар 2848 хөлөг онгоц манай улсын нэр дээр бүртгэлтэй байгаагаас 500 гаруй усан онгоц байнгын үйл ажиллагаа явуулдаг байна. ${ }^{8}$

4. БНСУ-ын гадаад худалдааны өнөөгийн байдал

2007 оны БНСУ-ын эдийн засгийн хямрал нь гэнэтийн тохиолдол байсан бол 2016 оны эдийн засгийн байдлыг судлаачид ихээхэн анхааралтай ажиглах боллоо. Дэлхийн эдийн засгийн өсөлт удааширч нефть болон бусад ашигт малтмалын үнэ унаснаар нэг талдаа ихэнх түүхий эдээ гаднаас авдаг БНСУ-ын худалдааны тэнцэлд ашигтай

8 http://www.shuud.mn/content/read/452958.htm?commentCheck=80 
мэт харагдаж байгаа боловч нөгөө талдаа алдагдал хүлээх боллоо. Тухайлбал БНСУ-ын усан онгоц үйлдвэрлэлийн салбар дахь гол захиалагчид болох Саудын Араб, АНЭУ зэрэг томоохон захиалагчид гэрээгээ цуцалсан. Үүнийг дагаад усан онгоцны үйлдвэрлэлийн дагалдах бүх салбар уналтанд орсон. Энэ байдлыг 2014 оноос ярьж эхэлсэн бөгөөд “БНСУ-ын эдийн засагт харанхуй шөнө айсуй” тухай багагүй бичиж байсан. Мөн автомашины дэлхийн зах зээлийн эрэлт багассантай холбоотой энэ салбар дахь үйл ажиллагаа доголдоход хүрээд байна. Маш олон үйлдвэрүүд хаалгаа барьж орон даяар газар, үйлдвэр, оффисийн байруудыг түрээслэх тухай хаяг, рекламууд харах боллоо. Эдгээрийг дагасан олон мянган иргэд ажилгүй болж нийгэм дахь бухимдал, тодорхойгүй байдал газар авлаа. Гэвч өнөөгийн байдлаар эдгээр асуудлыг шийдвэрлэх оновчтой бодлого, санал, санаачлага хараахан гараагүй байна. БНСУ-ийн худалдааны ҮзҮҮлэлтийг товч судалж үзвэл дараах зураг харагдана. Үүнд:

\section{Экспорт Импорт /Мянган ам.доллар/}

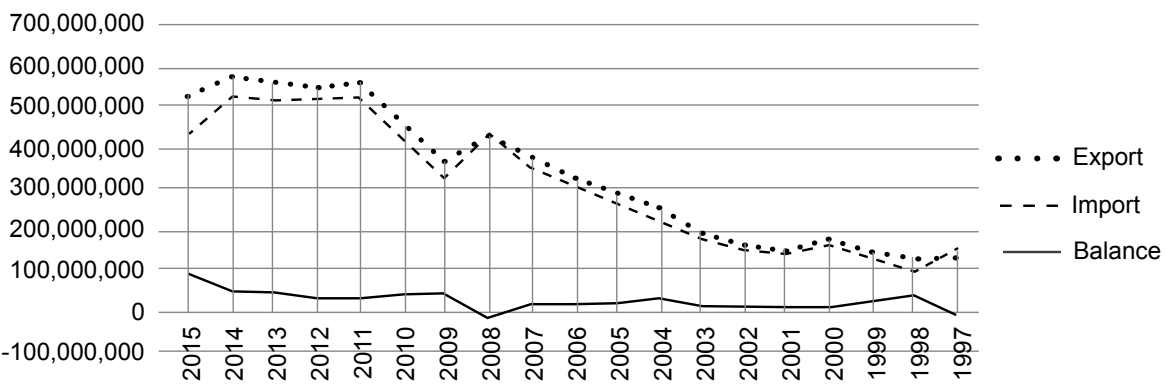

Эх сурвалж: $\underline{\text { http://stat.kita.net/ }}$

Дээрх графикаас харахад БНСУ-ын гадаад худалдаа нь 2007 оны Дэлхийн эдийн засгийн хямралын дараа 13 тэрбум ам.долларын алдагдалтай байсан бол 2015 оны байдлаар 90 орчим тэрбум ам.долларын ашигтай явагдсан байна. Энэ нь Худалдааны бодлого 2008 оноос хойш амжилттай хэрэгжиж ирсэнийг илтгэн харуулж байна.

БНСУ-ын ДНБ нь 2015 оны дүнгээр 1,377.8 тэрбум ам.доллар байгаа бол бараа бүтээгдэхүүний импорт нь 38.9\% буюу 535.9 тэрбум 
ам.доллар байна. ${ }^{9}$ Өөрөөр хэлбэл улсын нийт хэрэглээний $61.1 \%$-ийг дотооддоо үйлдвэрлэж, 38.9\%-ийг гадаадаас худалдан авдаг гэсэн үг. Нөгөө талаар нийт үйлдвэрлэлийн $45.9 \%$ буюу 632.4 тэрбум ам.долларын бүтээгдэхүүн үйлчилгээг экспортонд гаргажээ. ${ }^{10}$ Нийт үйлдвэрлэлийн бүтцийн хувьд дараах зураг харагдаж байна. Үүнд:

БНСУ-ын Үйлдвэрлэлийн бүтэц

\begin{tabular}{|c|c|c|c|}
\hline Он & 1 шат & 2 шат & 3 шат \\
\hline 2014 & 2.3 & 38.1 & 59.6 \\
\hline 2015 & 2.3 & 38 & 59.7 \\
\hline
\end{tabular}

1 дүгээр шатний үйлдвэрлэлд хөдөө аж ахуй, газар тариалан, загас агнуур, 2 дугаар шатны үйлдвэрлэлд уул уурхай, аж үйлдвэр, барилга, эрчим хүч, газ, 3 шатны үйлдвэрлэлд 1, 2 шатнаас бусад бүх салбар багтах бөгөөд ихэвчлэн үйлчилгээний салбар багтдаг.

Тухайн улсын худалдааны хамгийн гол хэмжүүр нь экспорт, импортын үзүүлэлтүүд юм. БНСУ-ын албан ёсны Статистикийн мэдээллийн үйлчилгээний байгууллагаас авсан тоо баримтыг графикт оруулж харваас дараах зураг харагдана. Үүнд:

БНСУ-ын нийт бараа, үйлчилгээний импорт, эхний 10 улс

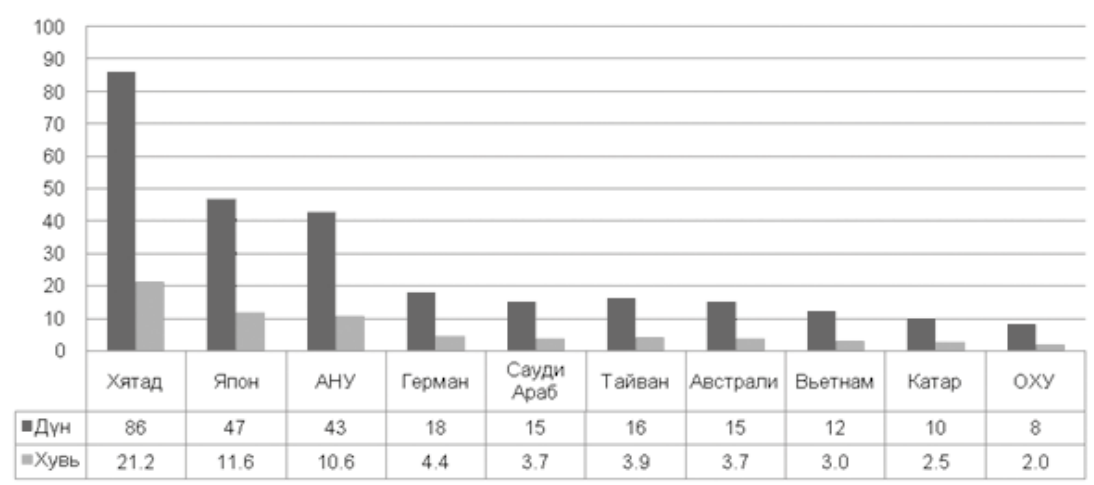

Эх сурвалж: $\underline{\text { http://kosis.krl }}$

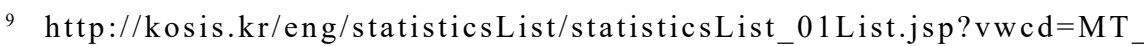
ETITLE\&parmTabId=M_01_01\#SubCont

10 Мөн тэнд
} 
Монгол Улсын хувьд БНСУ-д гаргаж буй бүтээгдхүүн, үйлчилгээний экспортын хэмжээ 66.6 сая ам.доллартай тэнцэж БНСУ-ын нийт импортод эзлэх хэмжээ $0.01 \%$ болж байна. 86 тэрбум ам.доллартай тэнцэх хэмжээний импортын бүтээгдэхүүн, үйлчилгээг БНХАУ-аас авдаг бөгөөд 33\% нь цахилгаан бараа, $12 \%$ нь цөмийн реактор, 7\% нь ган эзэлдэг байна. ${ }^{11}$

БНСУ-ын нийт бараа, үйлчилгээний импорт, эхний 10 бүтээгдэхүүний бүлэг

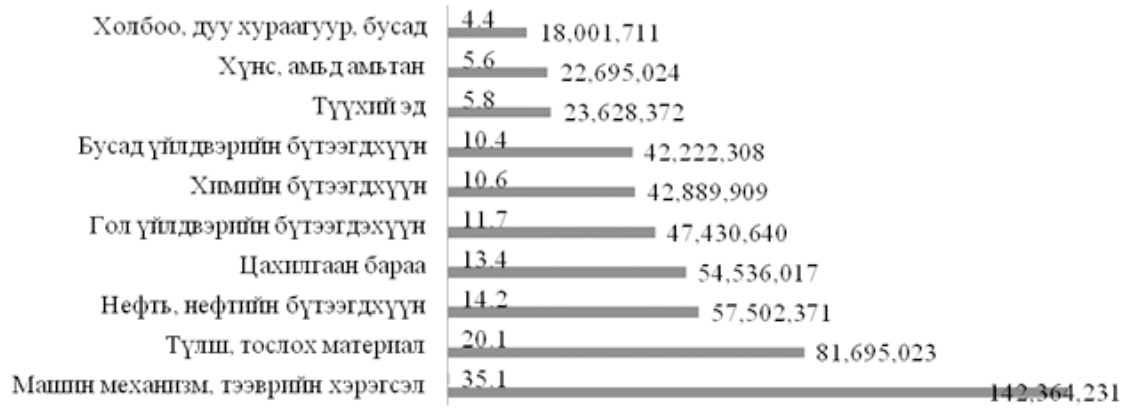

Эх сурвалж: $h t t p: / / k o s i s . k r /$

Нийт импортын 142 тэрбум ам.доллар буюу 35.1\%-ийг машин механизм, бусад тээврийн хэрэгсэл, 81 тэрбум ам.доллар буюу $20.1 \%$ ийг түлш, тослох материал, 14.2\%-ийг нефть, нефтийн бүтээгдэхүүн эзэлж байна.

11 http://kosis.kr/ 
БНСУ-ын нийт бараа, үйлчилгээний экспорт, эхний 10 улс

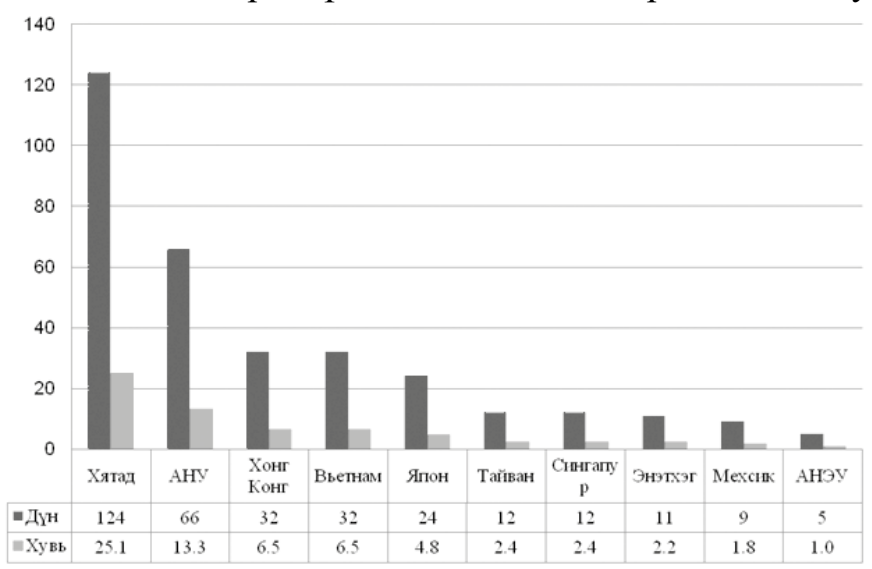

Эх сурвалж: http://kosis.kr/

Монгол Улсын бүтээгдэхүүн, үйлчилгээний импортын дүн 258 сая ам.доллартай тэнцэж БНСУ-ын нийт бараа, үйлчилгээний экспортод $0.04 \%$-ийг эзэлж байна.

124 тэрбум ам.доллартай тэнцэх бүтээгдэхүүн, үйлчилгээг БНХАУ-д экспортонд гаргадаг бөгөөд 36\% нь цахилгаан бараа, 13\% нь мэрэгжлийн багаж хэрэгслэл, $11 \%$ нь цөмийн реактор, бойлуур болон бусад тоног төхөөрөмж ордог.

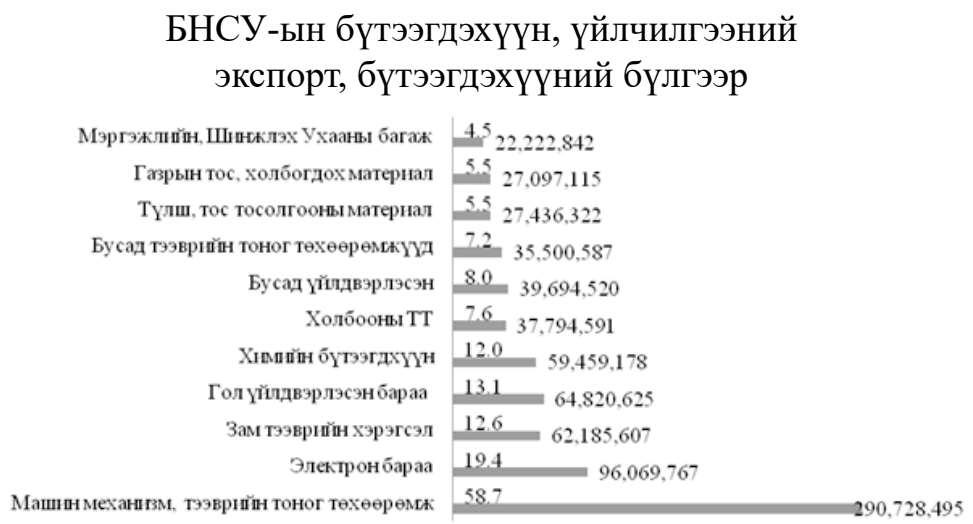

Эх сурвалж: $h t t p: / / k o s i s . k r /$ 
Нийт экспортын 58.7\% буюу 290 тэрбум ам.долларыг машин механизм, 19\% буюу 96 тэрбум ам.долларыг электрон бараа, 12.6\% буюу 62 тэрбум ам.долларыг зам тээврийн хэрэгсэл эзэлж байна.

БНСУ-ын худалдааны бодлого. БНСУ нь Дэлхийн худалдааны байгууллагад 1968 оны 7 дугаар сарын 2-ны өдөр элссэн байна. ${ }^{12}$ Дэлхийн худалдааны байгууллагаас гаргасан 2015 оны тайланд 2008 оны дэлхийн эдийн засгийн хямралын дараагаар БНСУ-ын экспорт давамгайлсан эдийн засаг маш хурдан хугацаанд сэргэсэн нь гадаад худалдаагаа эрчимжүүлж, түүнийг дэмжих макро эдийн засгийн болон санхүүгийн олон талын бодлого хэрэгжүүлсэний үр дүн байсан. OECD орнуудын дотроос эдийн засгаа сэргээх хамгийн их дүнтэй уян хатан мөнгөний бодлого, сангийн бодлого хэрэгжүүлсэн улс нь БНСУ байсан. Мөн эдийн засаг нь том эсвэл байгалийн баялаг арвин улсуудтай Чөлөөт худалдааны гэрээ байгуулж гадаад худалдааг эрчимжүүлсэн байдаг. 2008 онд дэлхийд 12-рт эрэмблэгдэж байсан улс өнөөдрийн байдлаар 7 дахь том экспортлогч улс болсон нь эдийн засгийн экспорт ямар хурдан хугацаанд сэргэж хөгжсөнийг харуулж байна. ${ }^{13}$

БНСУ дахь худалдааны бодлогын өөрчлөлт. 1953-1961 оны хооронд Импортыг орлох бодлого баримтлан хүнсний болон өргөн хэрэглээний бүтээгдхүүнээр дотоодын хэрэгцээг ханган, тэдгээрийн орц болох гурил, сахар, даавуу зэргийг ихээр нийлүүлсэн байна. Эдгээрийг хэрэгжүүлэх арга хэрэгслэл нь өндөр тариф, импортын зөвшөөрөл, гадаад валютын олон талт систем, бага хүүтэй санхүүгийн зах зээлийн бодлогууд байжээ. Энэ үед ДНБ-ийн 2\%ийг экспорт эзлэж, экспортын барааны 90 гаруй хувь нь анхдагч бүтээгдхүүн байсан. Энэ үед үйлдвэрлэн гаргасан бүтээгдхүүнийг дотоодын зах зээл шингээж чадахгүй болсон төдийгүй валютын хэрэгцээ өссөн зэрэг сөрөг үр дагаварууд гарч эхэлсэн.

1962-1972 оны хооронд Экспортыг дэмжих бодлого болгон өөрчилж Экспортын аж үйлдвэрийн комплекс, Экспортын чөлөөт бүсүүд байгуулсан ба үр дүнд нь эдийн засгийн бүтэцэд онцгой өөрчлөлт гарсан. Өөрөөр хэлбэл ХАА бүтээгдхүүний үйлдвэрлэлээс

$12 \mathrm{http} / / /$ www.wcoomd.org

13 Дэлхийн худалдааны байгууллагын тайлан, БНСУ-ын гадаад худалдааны бодлого, Улаанбаатар, 2015. 
Аж үйлдвэрийн бүтээгдэхүүн үйлдвэрлэгч орон болсон байна. Мөн ҮҮнд санхүүгийн салбарын шинэчлэл, бодлого, оновчтой арга замууд ихээхэн эерэг нөлөө үзүүлсэн байдаг.

1973-1979 оны Хүнд болон Химийн үйлдвэрийн хөгжлийг дэмжих бодлого баримталж ирсэн төдийгүй эдийн засгийг илүү аюулгүй болгох, хөгжлийн шинэ шатанд гарч, олон улсын хэмжээний өрсөлдөхүйц орон болох зорилтын хүрээнд хийгдсэн байна. Голлох үйлдвэрүүдээс дурдвал: ган, машин механизм, петрохимийн бүтээгдэхүүн, усан онгоц үйлдвэрлэл, цахилгаан бараа зэрэг багтдаг. Харин үйлдвэрлэлийн хүчин чадлын хэтрэлт, инфляцийн өсөлт, нөөцийн хомсдол, авилгал, хээл хахууль нэмэгдэж, гадаад зах зээлээс зээл авахад Засгийн газар нь баталгаа гаргаж байсан тул улсын өр их хэмжээгээр нэмэгдсэн.

1980-1994 оны Импортын либеральчлал болон аж үйлдвэрийн салбарын тэнцвэржүүлэлэх бодлогын хүрээнд өөрийн орны зах зээлийн гадаад зах зээлд нээн бараа үйлчилгээ, гадаадын шууд хөрөнгө оруулалт, санхүүгийн зах зээл салбарууд дээр хэрэгжүүлж эхэлсэн. Энэ үеэс хоёр талт болон олон талт Чөлөөт хадалдааны хэлэлцээрүүдийг хийж эхэлсэн байна. Тэнцвэржүүлэх бодлогын хүрээнд даавуу, ган, автомашин, хөлөг онгоц, хүнд цахилгаан тоног төхөөрөмж болон бордооны үйлдвэрүүдийн нэмэлт хөрөнгө оруулалтуудыг хязгаарлаж эхэлжээ. Үр дүнд нь 1980 онд 17.5 тэрбум ам.доллар байсан экспортын хэмжээ 2009 онд 363.5 тэрбэм ам.доллар болон даруй 21 дахин нэмэгджээ.

1995 оноос өнөөг хүртэл илүү нээлттэй худалдаа руу чиглэсэн бодлого баримтлах болж хамгийн анх удаа буюу 1999 онд Чили улстай албан ёсны Чөлөөт худалдааны гэрээ байгуулав. Ерөнхийдөө өөрийн орны зах зээлд гадаад зах зээлийг нэвтрэх үүд хаалгыг чөлөөлж, бус нутгийн болон олон улсын эдийн засаг, худалдааны интеграцид нэгдэх эхлэлүүд тавигдаж нээлттэй болж эхэлсэн. Энэ бодлогын үр дүнд экспорт улам бүр нэмэгдэж дэлхийн зэх зээлд тэргүүлэгч салбаруудтай том улс болсон боловч нийлүүлэлтийн илүүдэл, санхүүгийн салбарын гажуудал, төр, хувийн хэвшлийн хуувилдаан хүчээ авч, нийгэмд үндсэрхэг үзэл хүчээ авч гадаадын бүтээгдхүүний дотоодын зах зээл дээрх өрсөлдөөн үгүй болсон. 
Монгол улс, БНСУ-ын худалдааны харилцаа

\section{Монгол Улс, БНСУ-ын худалдааны харилцаа}

Монгол Улс, БНСУ-ын эдийн засгийн харилцаа өнгөрсөн 26 жилийн хугацаанд харилцан идэвх чармайлтаар дүүрэн байж, харилцаа тогтож эхлэх эхний жилээс буюу 1990 оны 3 дугаар сарын 26-ны өдрөөс эхлэн хоёр орны төр засгийн тэргүүнүүд олон санал, санаачлагыг дэвшүүлжээ. Тухайлбал, Сайд нарын Зөвлөлийн дарга Ж.Гунгаадорж, МАХН-ын Төв хорооны улс төрийн товчооны гишүүн, Төв хорооны нарийн бичгийн дарга, ГЯЯ-ны сайд Ц.Гомбосүрэн, Төлөвлөгөө эдийн засгийн улсын хорооны нэгдүгээр орлогч дарга, Төрийн сайд Т.Намжим, ЭЗГХХЯ-ны орлогч сайд Ц.Молом, ШУТДБУХ-ы орлогч дарга Ц.Сэджав, Зам тээврийн орлогч сайд, Иргэний агаарын тээврийн удирдах газрын дарга Д.Сүрэнхорлоо, Соёлын яамны орлогч сайд Д.Нарантуяа нар бүгд нэгэн санаагаар дараах саналыг тавьж байсан тухай түүхэн баримт Гадаад Харилцааны Яамны төв архивт хадгалагдаж үлдсэн байдаг. Үүнд: Худалдаа эдийн засаг, ШУТ, соёл, жуулчин, иргэний агаарын тээвэр, зэс, молебдин, цайр, газрын ховор элемент орборлох, баяжуулах, боловсруулах, бага оврын машин тоног төхөөрөмж угсрах, зарим эд анги метал хийцийг угсрах, үйлдвэрлэх, үйлдвэрийн зохиулалттай төрөл бүрийн цавуу, химийн мяндас гаргаж авах, дэлхийн зах зээлд өрсөлдөх чадвартай хөнгөн үйлдвэрийн гаралтыг нэмэгдүүлэх, электрон тоног төхөөрөмж угсрах, түүний суурь материал бэлтгэх, хамтарсан үйлдвэр байгуулах, газар тариалан, коксжих нүүрс худалдах, тээврийн 3 талт хэлэлцээ байгуулах, Солонгос барааг Монголоор дамжуулан Европийн зах зээлд гаргах, ШУТ, мэдээллийн салбарт хамтрах, соёлын солилцоо хийх, жуулчид хүлээн авах зэрэг асуудал багтаж байв.

1990 онд Ерөнхий сайд Д.Бямбасүрэнд БНСУ-аас Монгол Улсад суух Онц бөгөөд Бүрэн эрхэт элчин сайд Квон Ён Сүн хэлэхдээ: Хятадын төмөр замын Тяньжин боомтын ачаалал их тул ачаа тээвэр нэмэх боломж бага юм. Иймд Манжуураар 450-500 км төмөр зам тавивал Хуладао боомтыг ашиглаж болох бөгөөд Хятадын талд ч ашигтай. Монголд ч 400-500 км төмөр зам барих шаардлагатай. ОУВС, АХБ зэргээс тусламж авах урьдчилсан тооцоог гаргасан байх 
хэрэгтэй ${ }^{14}$ хэмээн хоёр улсын худалдааны хөгжлийн талаар санал солилцож байсан түүхтэй.

Дээрх албаны хүмүүсийн БНСУ-ын талд тавьсан үндсэн санааг нэгтгэн дүгнэвээс дараах 4-н санаа гарч байна. Үүнд: 1. Хамтарсан үйлдвэр барих. 2. Байгалийн баялаг ашиглах. 3. Шинжлэх ухаан техникийн харилцаа холбоог хөгжүүлэх. 4. Төмөр зам барих явдал байв. ${ }^{15}$

БНСУ-ын олон судлаач шинжээчдийн үзэж буйгаар манай улсын зах зээл жижиг, далайд гарцгүй, хоёр их гүрнээс нэлээд хамааралтай байдаг боловч байгалийн баялгаар дэлхийн 10 том улсын нэг гэдэг. Энэ нь байгалийн баялаггүй улсын хувьд урт хугацаанд нөөцөө баталгаажуулж авах бодлогын нэг субьект нь Монгол Улс болж байна. Харин манай улсын хувьд хамгийн энгийнээр тайлбарлавал Монгол Улс, БНСУ-ын худалдааны харилцаа нь хоёр хөршийн эдийн засгийн нөлөөг саармагжуулах, нэг улсаас хараат байдлыг багасгах, гадаад худалдааны олон эх үүсвэртэй болох, бүс нутгийн эдийн засгийн интеграцид нэгдэн орох, олон улсад өрсөлдөх чадвараа нэмэгдүүлэх зэрэг арга замаар дотоод эдийн засгийн тогвортой байдлыг хангах, улсын төсөв, ажлын байр нэмэгдүүлэх давхар давхар эрх ашгийг хөндсөн чухал асуудал билээ.

БНСУ-ын Монгол Улс дахь импорт

/Сая ам.доллар/

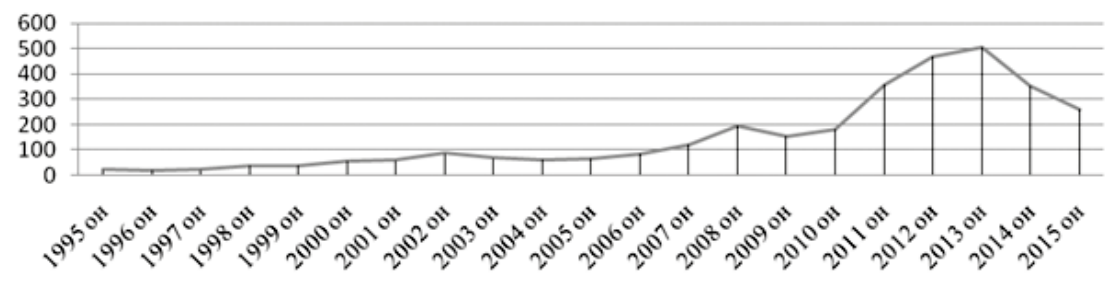

Эх сурвалж: http://customs.gov.mn/

14 Монгол Улсын ГХЯ-ны Гадаад харилцааны Төв архив, фонд-, данс №2, ХН-112, 33тал.

15 И.Энхболд, “Монгол Улс, БНСУ-ын эдийн засгийн харилцааны зарим асуудал”, Солонгос судлал сэтгүүл, Улаанбаатар, 1(2016), 113 дугаар тал. 
БНСУ-ын импортын үзүүлэлтээр Монгол Улсын хэмжээнд 4 дүгээр байранд байгаа ба нийт импортын 6.7 хувийг эзэлж байна. 2015 оны импортын бууралтад гол нөлөөлсөн хүчин зүйл нь нефтийн бүтээгдэхүүн бөгөөд ОХУ-ын нефтийн бүтээгдхүүний үнийн бууралтаас ихээхэн шалтгаалжээ. 2015 онд нийт импорт 258 сая ам.доллар байгаагаас нефтийн бүтээрдэхүүн 28 сая ам.доллар, хөнгөн цагаан бүтэц, энд анги 26 сая ам.доллар, ачааны тэрэг 15 сая ам.доллар, бусад бараа бүтээгдэхүүн 188 сая ам.долларийг тус тус эзэлж байна.

Монгол Улс, БНСУ-ын хооронд явагдсан худалдааны тэнцлийг 1990 оноос 2015 оныг хүртэл нийтэд нь тооцож үзвэл нийт экспорт 565 сая ам.доллар, нийт импорт 3,203 сая ам.доллар, нийт худалдаа 2,638 сая ам.долларын алдагдалтай байна. Нэмж хэлэхэд манай иргэдийн мөрийтэй тоглоомонд оруулсан мөнгө, боловсрол, эрүүл мэндийн салбарт оруулсан мөнгийг тооцож үзвэл дээрх тоо нэмэгдэх нь дамжиггүй. Энэ талаарх судалгааг цаашид анхааралдаа авч эрдэмтэн, судлаач, шинжээчид бодлогын түвшинд судлах зайлшгүй хэрэгцээ байгаа нь харагдаж байна.

\section{БНСУ-ын Монгол Улс дахь экспорт \\ /Сая ам.доллар/}

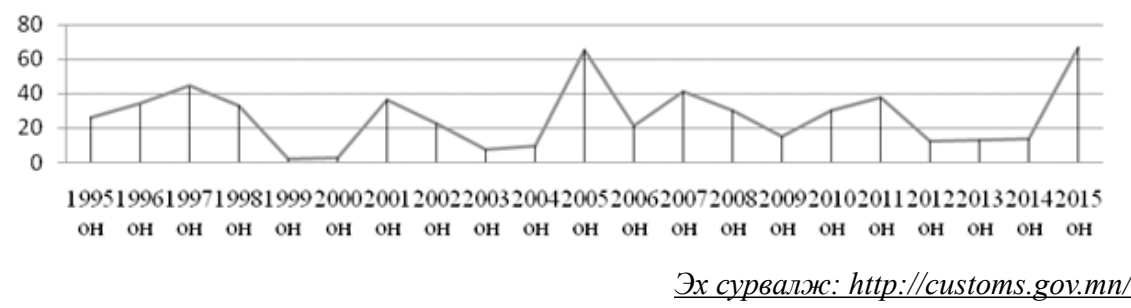

БНСУ-д гаргасан бараа, бүтээгдхүүний экспортын үзүүлэлтээр Монгол Улсын хэмжээнд 10 дугаар байранд орж буй боловч нийт экспортын 0.2 хувийг эзэлж байна. 2015 оны экспортийн огцом өсөлтөнд 10.9 сая ам.долларын үнэ бүхий молебдиний баяжмал, 46 сая ам.долларын үнэ бүхий зэсийн баяжмал экспортлож эхэлсэн нь 2015 оны үзүүлэлтийг өсгөх гол хүчин зүйл болжээ. Нийт 56.9 сая ам.долларын үнэ бүхий молебдин, зэсийн баяжмалыг хасаж тооцвол 
экспортын хэмжээнд төдийлөн өөрчлөлт ажиглагдахгүй байна. Мөн, экспортын гол нэрийн бараанд жонш 720 мянган ам.доллар, хайлуур жоншны хүдэр 664 мянган ам.доллар, гянт болдын хүдэр 512 мянган ам.доллар, сүлжмэл гадуур цамц 242 мянган ам.доллар, ноолууран зүйлс 147 мянган ам.доллар, ямааны арьс 100 мянган ам.доллараар тус тус багтаж байгаа юм.

Монгол Улсын экспортын ихэнх хувийг түүхий эд, материал эзэлж буй тул Чөлөөт худалдааны хэлэлцээ Монголын макро эдийн засагт нөлөө үзүүлэхгүй гэж судлаачид үзэж буй боловч нөгөө талаараа манай улсын үйлдвэрлэлийн түвшинг дэлхийн зах зээлд гаргах үүд, хаалга байж болох юм. ${ }^{16}$

\section{Дүгнэлт}

1. Монгол Улс, БНСУ-ын хооронд албан ёсны дипломат харилцаа тогтоосон 1990 оноос хойш үе үеийн төрийн тэргүүн нар хамтарсан үйлдвэр барих, байгалийн баялгийг хамтран ашиглаж ашиг олох, шинжлэх ухаан, технологи нэвтрүүлэх зэрэг үндсэн чиглэлийг барьж, өнөөг хүртэл хоёр тал харилцан санал, санаачлага тавьсаар иржээ. Эдгээр саналыг бодитоор хэрэгжүүлэх цаг нэгэнт болсон байна гэж судлаач миний бие үзэж байна. Учир нь бид 27 жилийн турш нэг адил зүйлийг давтан ярисаар иржээ.

2. Хоёр орны нийт худалдааны зөрүү 1990-2015 он хүртэл -2.6 тэрбум ам.доллараар хэмжигдэж байна. Өөрөөр хэлбэл, энэ хэмжээний хөрөнгө БНСУ-д орсон гэсэн үг. Энэ байдлыг хоёр талын шийдвэр гаргах түвшнийхэн, эдийн засгийн чиглэлийн эрдэмтэн судлаачид анхааралдаа авч худалдааны алдагдалыг багасгах талаар судлах цаг болжээ.

3. Дэлхийн түвшинд 100 сая ам.доллараас дээш хөрөнгө оруулалт орж ирсэн тохиолдолд томоохон хэмжээний хөрөнгө оруулалт гэж тооцдог. Гэвч Монгол Улсад БНСУ-ын хөрөнгө оруулалт хамгийн их орж ирсэн 2008 онд нийтдээ 60

16 И.Энхболд, Монгол Улс, “БНСУ-ын эдийн засгийн харилцааны зарим асуудал”, Солонгос судлал сэтгүүл, Улаанбаатар, 1(2016), 113 дугаар тал. 
орчим сая ам.доллар байгаа нь бусад орнуудын манай улсад оруулж буй хөрөнгө оруулалттай харьцуулахад чамлалттай үзүүлэлт юм. Цаашид энэ тал дээр түлхүү анхаарч ажиллах шаардлагатайг харуулж байна.

4. Эдийн засагчдийн судалгаануудыг харвал Гравити, Ерөнхий тэнцлийн арга, Харьцангуй давуу талын тооцоо, Импортын харьцангуй давуу талын тооцоо зэрэг эдийн засгийн онол, практикийн олон аргаар Монгол Улс, БНСУ-ын хооронд Чөлөөт худалдааны гэрээ хийх нь ашигтай бөгөөд хоорондын худалдааг нэмэгдүүлэх тооцоо гарчээч байна. Гэвч зөвхөн эдийн засгийн тооцоо шинжилгээнд тулгуурлах бус улс төр, олон улсын харилцаа, бүс нутгийн интеграцийн түвшинд бодит судалгааг ч мөн хийх ёстой гэдэг нь харагдаж байна.

\section{Ном зүй:}

1. “Солонгос судлал” сэтгүүл, Mongolian journal of Korean Studies, Улаанбаатар хот, 2016-1

2. Р.Амаржаргал, Зүүн Хойд Азийн чөлөөт худалдааны гэрээ ба Монгол. Судалгааны ажил. Улаанбаатар хот, 2007

3. Р.Батмэнд, Б.Хулдорж, Д.Нямцэрэн, Н.Отгонсайхан, Эдийн засгийн интеграц: Чөлөөт худалдааны хэлэлцээрийн экспортын бүтцэд үзүүлэх нөлөө. Судалгааны ажил УБ, 2012

4. Н.Батнасан, Монгол Улсын экспортыг дэмжих бодлого зохицуулалтын тулгамдсан асуудлууд. Диссертаци, МУИС, УБ, 2000

5. Н.Батнасан, Уул уурхайд тулгуурласан эдийн засгийн өсөлт ба хөгжлийн стратеги. Монгол Улсын эдийн засаг, бизнесийн судалгаа, Эмхэтгэл, Улаанбаатар, 2012, МУИС ЭЗС, 197-209 дүгээр тал

6. Н.Батнасан, Н.Отгонсайхан, Д.Нарандалай, Ц.Оюунбилэг, Худалдааны гол түнш орнуудтай Чөлөөт худалдааны хэлэлцээр байгуулах боломж болон эрсдэл. Бодлогын судалгаа, МУИС, УБ, 2012 
7. Д.Баяндалай, Монгол Улсын гадаад худалдааны бүтэц, байршилтын шинэчлэл. Диссертаци, ШУА, ЭЗХүрээлэн, УБ, 1994

8. П.Гантөмөр, Эдийн засгийн өсөлтөнд нөлөөлөгч зарим хүчин зүйлсийн шинжилгээ. Диссертаци. МУИС, УБ, 2001

9. Э.Гүргэмжав, Гадаад худалдаа. УБ, 1995

10. Э.Гүргэмжав, Гадаад худалдааны үйл ажиллагаа: судалгаа, үр дүн, аргачлал, Улаанбаатар хот, 2005

11. Л.Даваажаргал, Гадаад худалдаа ба ханшийн хэлбэлзэл. Судалгааны ажил, УБ, 2006, Товхимол-4, Монголбанк, 54-58 дугаар тал

12. Дэлхийн банк, Монгол Улс: Төсвийн зарлага болон санхүүгийн менежментийн тойм. УБ, 2002

13. И Жэ Ён, Жэ Сон Хүнь, Г.Мөнхнасан, "Монгол Улсын хөрөнгө оруулалтын орчин, БНСУ-ын ах ахуйн байгууллагууд Монголын зах зээлд өргөнөөр нэвтрэх нь", БНСУ-ын гадаад эдийн засгийн бодлогын судалгааны хүрээлэн, Улаанбаатар хот, 2014.

14. П.Лувсандорж, БНМАУ-ын эдийн засгийн хөгжлийн зангилаа асуудлууд. ШУАХ, УБ, 1980

15. Монгол Улсын худалдааны бодлого ба хүний хөгжил, ГХЯ, НҮБ-ийн Хөгжлийн Хөтөлбөр, УБ, 2008

16. Ч.Наранчимэг, Эдийн засгийн өсөлтөд нөлөөлөгч хүчин зүйлсийн шинжилгээ. Диссертаци, Удирдлагын академи, УБ, 2006

17. Б.Пүрэв, Монгол Улсын зэсийн үйлдвэрлэл, түүний орлогын хуваарилалтын асуудал. Судалгааны ажил, УБ, 2011

18. Монгол банкны судалгааны хэсгийн эдийн засагч Л.Даваажаргал “Гадаад худалдаа ба ханшийн хэлбэлзэл"

19. Монгол Улсын их сургуулийн магистрант Д.Нарандалай "Гадаад худалдаанд дүн шинжилгээ хийх арга, аргачлал: ТАТАЛЦЛЫН ЗАГВАР”, УБ, 2009

20. Ч.Алтан-Өлзий, Г.Батзориг, А.Ундрал "Гадаад худалдааны Гравитацийн шинжилгээ” УБ, 2011

21. И.Энхболд, “Монгол Улсад өргөнөөр яригдаж буй төслүүдийн тойм”, эрдэм шинжилгээний илтгэл, УБ, 2015. 
22. И.Энхболд, Монгол Улс, БНСУ-ын эдийн засгийн харилцааны зарим асуудал, “Солонгос судлал” сэтгүүл, УБ, 2016-01.

23. С.Уянга "Монгол Улсын гадаад худалдаанд хийсэн өсөлт үр ашгийн шинжилгээ” УБ, 2012

24. Шим И Соб, Г.Мөнхнасан, Зүүн Хойд Азийн эрин үе ба Монголын эдийн засаг, Сөүл хот, 2015

25. Эдийн засгийн түншлэлийн тухай Монгол Улс, Япон улс хоорондын хэлэлцээр, УБ, 2015 он.

26. И.Энхболд, Олон улсын харилцааны хүрээлэнгийн Солонгос хэл дээрх өгүүллийн эмхэтгэл, УБ, 2016, 134 дүгээр тал. /“ 국제관계연구소한국어논문모음집", 편자: 이.엥흐벌뜨 (Enkhbold Ikhbayariin)(박영욱), 몽골과학아카데미, 국제관계연구소, 2016년, 134페이즈/

27. Зүүн Хойд Азийн үнэ цэнэ ба ирээдүй, Дангүг Их сургуулийн Монгол судлал, 2016/동몰의가치와미래, 단국대학교몽골연구소편, 2016/.

28. Евразийн сүлжээний өнгөрсөн, одоо, ирээдүй, 2014, Улаанбаатар, /유라시안네트워크과거, 현재그리고미래, 2014, 울란바토르/.

29. Евразийн эрин дахь Монгол Улс, БНСУ-ын ирээдүйн хамтын ажиллагааны яриа, хэлэлцээр, Монгол Улс, БНСУ-ын олон улсын семинар, Гадаад эдийн засгийн бодлогын хүрээлэн, 2016. /유라시아시대한몽미래협력대화, 한-몽골국제세미나, 대외경제정책연구원/, 2016

30. И Жай Ён, И Ши Ён, Д.Ганбаатар “Шинэ Азийн эрин дахь Монгол Улс, БНСУ-ын стратегийн хамтын ажиллагааны хандлага", Гадаад эдийн засгийн бодлогын хүрээлэн, $2010 \mathrm{oH}$, Сөүл. /이재영, 이시영, 두게르간바타르, “ 신 아 시아 시대 한 국 과 몽 골 의 전 략 적 협 력 방 안 ”, 대외경제정책연구원, 2010년, 서울/.

31. И Пён Рай, "Монгол Улс, БНСУ-ын хамтын ажиллагааны талаарх хэдэн санал” /이평래, “한-몽협력을위한몇가지제언", 2016/. 
32. И Жай Ён, Гүон Га Үон “Монгол Улс, БНСУ-ын хамтын ажиллагааны өнөөгийн байдал ба өсөх хандлага" /이재영, 권가원, “한국과몽골의경제협력현황과증진방안”, World Economy Today, 2016/.

33. One Northeast Asia Region, One Community, NEAR International Forum 2014, NEAR

34. И.Энхболд, Ж.Баясах "Historical Value and the Future of Eastern Mongolia II, International Conference of Eartern Mongolia Project" 2015, /이.엥흐벌뜨재, 바야사흐, "몽 골 에서 논 의 되 고 있는 프로 젝트 에 대한 개 요" , 동북아역사재단, 2015년/.

35. И.Энхболд, Ж.БаясахМонгол Улс, БНСУ-ын улс төрийн харилцааны салбарт дахь хамтын ажиллагааны өнөөгийн байдал. Монгол Улс, БНСУ-ын олон улсын семинар, 2016 он. /이.엥흐벌뜨, 재.바야사흐, “ 한 . 몽 관 계 정 치 외 교 분 야 협 력 현 황 과 과 제 " , 유라시아시대한몽미래협력대화, 한몽골국제세미나, 2016년/.

36. Helmers C. (2006): "Options for Mongolia for the Formation of Bilateral Free Trade Agreements-Options in Merchandise Trade: An Overview", Mongolian Ministry of Industry and Trade, Trade Analysis and Negotiations Unit (UNDP, GTZ, USAID).

37. "Korea-Mongolia Economic Relations: How Can They Be Reinforced?", world economy brief, 2016.

38. Historical Value and the Future of Eastern Mongolia II, International Conference of Eastern Mongolia Project 2015. Ulaanbaatar.

39. One Northeast Asia Region, One Community, NEAR International Forum 2014, Presentation book, 2014, Russia.

40. www.un.int

41. www.ubinfo.mn

42. http://customs.gov.mn/

43. http://www.iss.gov.mn

44. http://www.mfa.gov.mn

45. http://koreaexim.go.kr/

46. http://www.kita.org/

47. http://kotra.or.kr/

48. http://www.wcoomd.org 


\section{TRADE RELATIONS BETWEEN MONGOLIA AND REPUBLIC OF KOREA}

\section{I.Enkhbold}

Prior to conducting research on trade relations between Mongolia and the Republic of Korea, the thesis attempted to assess the trade policy of Mongolia, previous research on the bilateral trade relations, current trade relations and the trade regime of the two countries. Whilst, progress has been made in the political aspect of the two countries, the economic relations have not seen sufficient growth. It is assumed that establishing Economic Partnership Agreement as one of the ways to improve the current dynamic baseline. It is expected that directing investment from Republic of Korea into mega projects in Mongolia, which have been pending for 27 years would be pivotal move in advancing bilateral trade relations to a new level.

Keywords: Mongolia, Republic of Korea, Foriegn trade, Bilateral relations 